\title{
Immunohistochemical and qPCR Detection of SARS-CoV-2 in the Human Middle Ear Versus the Nasal Cavity: Case Series
}

\author{
Arwa Kurabi $^{1,4}$ (D) Kwang Pak ${ }^{1} \cdot$ Adam S. DeConde $^{1} \cdot$ Allen F. Ryan $^{1,2,3} \cdot$ Carol H. Yan $^{1}$
}

Received: 14 July 2021 / Accepted: 20 August 2021 / Published online: 28 August 2021

(c) The Author(s) 2021

\begin{abstract}
Viral infections have already been implicated with otitis media and sudden sensorineural hearing loss. However, the pathophysiology of COVID-19 as it relates to otologic disorders is not well-defined. With the spread of SARS-CoV-2, it is important to evaluate its colonization of middle ear mucosa. Middle ear and nasal tissue samples for quantitative RT-PCR and histologic evaluations were obtained from post-mortem COVID-19 patients and non-diseased control patients. Here we present evidence that SARS-CoV-2 colonizes the middle ear epithelium and co-localizes with the primary viral receptor, angiotensin-converting enzyme 2 (ACE2). Both middle ear and nasal epithelial cells show relatively high expression of ACE2, required for SARS-CoV-2 entry. The epithelial cell adhesion molecule (EpCAM) was use as a biomarker of epithelia. Furthermore, we found that the viral load in the middle ear is lower than that present in the nasal cavity.
\end{abstract}

Keywords COVID-19 $\cdot$ Coronavirus $\cdot$ SARS-CoV-2 $\cdot$ Middle ear $\cdot$ Nasal cavity $\cdot$ qPCR $\cdot$ Immunohistochemistry

\section{Introduction}

COVID-19 caused by the severe acute respiratory syndrome coronavirus 2 (SARS-CoV-2) has been linked to acute otitis media (OM) [1], as well as longer term otologic sequelae including hearing loss and tinnitus [2]. In a survey of admitted COVID-19 patients, 1 in 10 reported changes in their hearing [3]. Other respiratory viruses are known to cause OM through increased susceptibility to bacterial OM or, less commonly, direct viral infection of the middle ear (ME) [4, 5]. The pathophysiology of COVID-19 associated otologic disorders has not yet been elucidated.

Although the nasal cavity is a known viral entry site, there is little data as to whether the mucosal epithelium lining the $\mathrm{ME}$ is infected and if so, the resulting clinical implications.

Arwa Kurabi

akurabi@ucsd.edu

1 Department of Surgery/ Division of Otolaryngology- Head and Neck Surgery, University of California, San Diego, USA

2 Department of Neuroscience, University of California, San Diego, USA

3 San Diego VA Healthcare System, San Diego, CA, USA

4 University of California San Diego, School of Medicine, 9500 Gilman Drive, La Jolla, CA 92093-0666, USA
One prior qPCR study demonstrated the presence of SARSCoV-2 RNA in the mastoid and ME in autopsy specimens [6], but specific infected tissue tropism was unknown. More information is needed regarding ME colonization, viral distribution, the potential ME effects of COVID-19 and its relationship to viral infection in the nasal cavity.

In this case series, we examined the ME and nasal septal tissue from post-mortem COVID-19 patients for evidence of SARS-CoV-2 colonization. We also evaluated these tissues for expression of the primary viral receptor, angiotensinconverting enzyme 2 (ACE2).

\section{Materials and Methods}

\section{Subjects}

ME and nasal cavity mucosal samples were obtained postmortem from six COVID-19 patients (P1-6) with PCR-confirmed SARS-CoV-2. The median age at death was 65 years (range, 44 to 91 years), and the time from COVID-19 symptom onset to autopsy ranged from 6 to 37 days (see Table 1 for further clinical details). All subjects had acute respiratory distress syndrome (ARDS) and hearing loss was present in two of the six subjects (P1 and P5). PCR-confirmed, COVID-19 negative patients (P7-10) served as controls 
Table 1 Clinical and demographic information from patients utilized in this study

\begin{tabular}{|c|c|c|c|c|c|c|c|c|c|}
\hline \multirow[t]{2}{*}{ Patient ID } & \multirow[t]{2}{*}{ Gender } & \multirow[t]{2}{*}{ Age (years) } & \multirow[t]{2}{*}{$\begin{array}{l}\text { Days between diag- } \\
\text { nosis and death }\end{array}$} & \multirow{2}{*}{$\begin{array}{l}\text { Days between } \\
\text { symptoms and } \\
\text { death }\end{array}$} & ARDS & $\begin{array}{l}\text { Acute renal } \\
\text { failure }\end{array}$ & HTN & Diabetes & Hearing loss \\
\hline & & & & & \multicolumn{2}{|c|}{ Hospitalization } & \multicolumn{3}{|l|}{ PMH } \\
\hline \multicolumn{10}{|l|}{ COVID-19 } \\
\hline 1 & $\mathrm{~F}$ & 88 & 17 & 18 & $\mathrm{Y}$ & $\mathrm{N}$ & $\mathrm{Y}$ & $\mathrm{N}$ & $\mathrm{Y}$ \\
\hline 2 & M & 65 & 35 & 37 & $\mathrm{Y}$ & $\mathrm{Y}$ & $\mathrm{N}$ & $\mathrm{N}$ & $\mathrm{N}$ \\
\hline 3 & M & 57 & 28 & 28 & $\mathrm{Y}$ & $\mathrm{Y}$ & $\mathrm{N}$ & $\mathrm{Y}$ & $\mathrm{N}$ \\
\hline 4 & $\mathrm{~F}$ & 44 & 6 & 8 & $\mathrm{Y}$ & $\mathrm{Y}$ & $\mathrm{N}$ & $\mathrm{N}$ & $\mathrm{N}$ \\
\hline 5 & $\mathrm{~F}$ & 91 & 3 & 6 & $\mathrm{Y}$ & $\mathrm{N}$ & $\mathrm{N}$ & $\mathrm{N}$ & $\mathrm{Y}$ \\
\hline 6 & M & 65 & 28 & 28 & $\mathrm{Y}$ & $\mathrm{Y}$ & $\mathrm{N}$ & $\mathrm{Y}$ & $\mathrm{N}$ \\
\hline \multicolumn{10}{|l|}{ Control } \\
\hline 7 & M & 35 & - & - & - & - & $\mathrm{N}$ & $\mathrm{N}$ & $\mathrm{N}$ \\
\hline 8 & $\mathrm{~F}$ & 44 & - & - & - & - & $\mathrm{Y}$ & $\mathrm{Y}$ & $\mathrm{N}$ \\
\hline 9 & $\mathrm{~F}$ & 39 & - & - & - & - & $\mathrm{N}$ & $\mathrm{N}$ & $\mathrm{N}$ \\
\hline 10 & M & 63 & - & - & - & - & $\mathrm{Y}$ & $\mathrm{N}$ & $\mathrm{Y}$ \\
\hline
\end{tabular}

$N$ No, $Y$ yes

with tissue obtained during routine otolaryngologic surgeries unrelated to middle ear or nasal mucosa abnormalities. The use of human tissues was reviewed and approved by the Institutional Review Board of the University of California San Diego School of Medicine. (IRB\#191,951 \& 151,473).

\section{Tissue Procurement and Processing}

ME and nasal septal mucosa were harvested endoscopically by attending otolaryngologists (CHY, ASD) within $3 \mathrm{~h}$ postmortem from COVID-19 patients or at time of otolaryngologic surgery for non-COVID-19 control cases (P7, P8, P9, P10). Given the limited tissue amount, samples were utilized for either RT-qPCR analysis (P1, P2, P3, P7, P8, P9, P10) or histological evaluation (P4, P5, P6, P7, P8). Samples were placed in trizol for RNA analysis or fixed in $4 \%$ paraformaldehyde for $24 \mathrm{~h}$ followed by paraffin embedding. Blocks were cut into $8 \mu \mathrm{m}$ sections for hematoxylin and eosin (H\&E) and all immunofluorescence staining.

\section{COVID-19 qPCR}

Quantitative RT-PCR for SARS-CoV-2 detection was used per the US Centers for Disease Control panel assay [7]. COVID-19 primers (N1, N2, and N3 -GENEWIZ) plus human GAPDH gene (Qiagen) were used to assess all clinical samples using the StepOnePlus PCR cycler system (Applied Biosystems). A quantitative synthetic SARSCoV-2 RNA: Spike 3' template (ATCC-VR3276SD) was used as a positive control template. Total RNA was extracted by Trizol/chlorophorm protocol (Invitrogen) and reverse transcribed using SuperScript-III (Invitrogen). The relative expression was normalized to that of human GAPDH gene present using the $\Delta \Delta \mathrm{C}_{\mathrm{t}}$ method.

Efficiency of primers was determined to be $95-100 \%$ by standard curve, and melt curves were used to assure the correct amplicon size. To calculate viral load, the quantitative synthetic COVID-19 template was used to generate a standard curve for quantification [8]. All experiments were performed in triplicates per biological sample with error bars depicting standard error. Statistical significance was determined by Wilcoxon non-parametric test with $\mathrm{p}<0.05$. Samples with $\mathrm{Ct}$ values $>38$ or undetectable were considered negative.

\section{Immunofluorescence}

Deparaffinized and hydrated sections were heated in citrate solution ( $\mathrm{pH}$ 6.0) for antigen retrieval (DAKO). After blocking for $1 \mathrm{~h}$. using 2\% BSA, sections were incubated with primary antibodies that were either from rabbit or mouse to: hEPCAM (Invitrogen 1:200), hACE-2 (Abcam 1:200), Muc5AC (Abcam, 1:200), SARS-CoV-2 Spike (Abcam, 1:100) [9] and SARS-CoV-2 nucleocapsid (Sinobiogical, 1:100) [10], overnight. Following further PBS washs, the appropriate Alexa-Fluor-conjugated secondary antibodies (Molecular Probes, Eugene, OR, 1:700) were incubated for $1 \mathrm{~h}$. at room temperature, washed in PBS, mounted in Slow fade for imaging. Immunostained slides were imaged with an FSX100 microscope (Olympus) and exposure-matched pictures from negative controls compared. 


\section{Results}

SARS-CoV-2 RNA expression in the ME and the nasal cavity are overall increased in COVID-19 subjects compared to non-infected patients control tissue, with higher expression in the nasal cavity compared to the ME (Fig. 1). ME mucosa from individuals $\mathrm{P} 1$ and $\mathrm{P} 3$ was positive for SARS-CoV-2 RNA by RT-qPCR with cycle thresholds ranging from 29-33. Meanwhile, in the nasal tissue, all three samples were positive for SARS-CoV-2 with cycle thresholds ranging in 23-32. The viral loads (Table 2) in the nasal cavity were significantly higher than in the ME for subjects $\mathrm{P} 1\left(2 \times 10^{5}\right.$ vs. $2 \times 10^{2}$ copies $\left./ \mu \mathrm{l}, \mathrm{p}<0.05\right)$ and P2 $\left(1 \times 10^{3}\right.$ copies $/ \mu \mathrm{l}$ vs. ME COVID-19 negative). There was no statistical difference in viral load for subject P3 $\left(3.8 \times 10^{2}\right.$ vs. $1 \times 10^{2}$ copies $/ \mu 1$, ME vs. nasal cavity).

Histological evaluations of tissue from patients P4, P5 and P6 all showed that expression of SARS-CoV-2 was found in both the ME and nasal septum which co-localized with ACE2 expression (Fig. 2). Expression of ACE2 was detected on surface epithelium identified by EPCAM. Both ME and nasal epithelial cells showed relatively high expression of ACE2 required for SARS-CoV-2 entry. Viral staining was not detected in COVID-19 negative and control ME and nasal samples. Paraffin sections were labeled with DAPI nuclear staining (blue) and the indicated Alexa 488-conjugated secondary antibodies (green) in representative sections in Fig. 2.

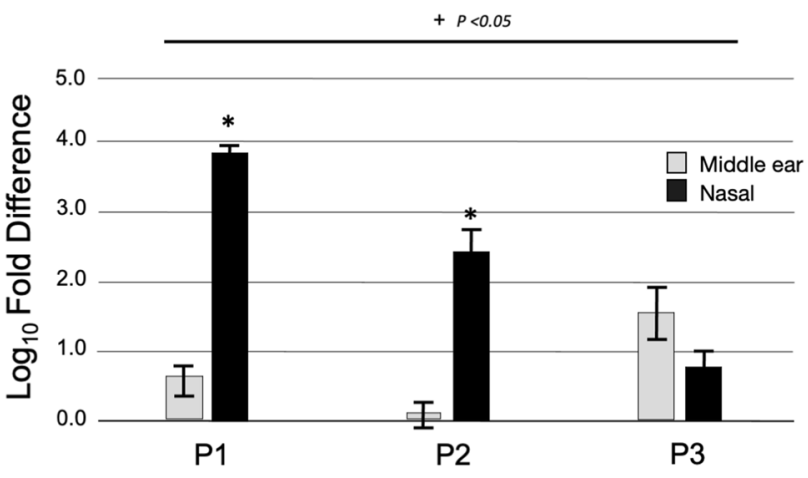

Fig. 1 SARS-CoV-2 RNA expression in the middle ear and nasal cavity. Expression depicted as $\log _{10}$ fold difference, normalized to control COVID-19 negative tissue (P7 and P8, septal mucosa). All COVID-19 ME and nasal cavity samples demonstrated statistically higher levels of SARS-CoV-2 RNA expression compared to control except for the ME sample for $\mathrm{P} 2$ as indicated by ${ }^{+}(\mathrm{p}<0.05)$. A noninfectious positive control template yielded strong positive results in each assay (data not shown). For subjects P1 and P2, the viral loads in the nasal cavity were higher than those in the ME, as indicated by $*(\mathrm{p}<0.05)$
Table 2 Quantitative RT-PCR data for SARS-CoV-2 detection in the nasal cavity and middle ear samples

\begin{tabular}{llllll}
\hline Patient ID & \multicolumn{2}{l}{ Nasal } & & \multicolumn{2}{l}{ Middle ear } \\
\cline { 2 - 3 } \cline { 5 - 6 } \cline { 5 - 6 } & Ct value & Viral load copies $/ \mu 1$ & & Ct value & $\begin{array}{l}\text { Viral load } \\
(\text { copies } / \mu 1\end{array}$ \\
\hline 1 & 23.2 & $2.4 \times 10^{5}$ & 31.2 & $2.2 \times 10^{2}$ \\
2 & 27.3 & $1.0 \times 10^{3}$ & 38.0 & - \\
3 & 32.5 & $9.3 \times 10^{1}$ & 29.6 & $3.8 \times 10^{2}$ \\
4 & ND & & ND & \\
5 & ND & & ND & \\
6 & ND & & ND & \\
7 & $>38$ & - & ND & - \\
8 & $>38$ & - & ND & - \\
9 & $>38$ & - & $>38$ & - \\
10 & $>38$ & - & $>38$ & - \\
\hline
\end{tabular}

ND stands for not determined. Samples with Ct values $>38$ were considered negative

\section{Discussion}

We demonstrate concomitant viral presence in the ME and nasal cavity, suggesting systemic infection of SARS-CoV-2 in the head and neck region. In the ME viral load due to other upper respiratory tract (URT) viral infections often varies with a range between $\left(10^{1}-10^{4}\right.$ copies/ $\left.\mu \mathrm{l}\right)[11,12]$ with higher viral loads typically associated with increasing URT infection severity $[12,13]$. Looking at COVID-19 studies in other organ systems, viral loads have been reported in the range of $10^{1}-10^{5}$ copies $/ \mu \mathrm{L}$ in gut and $10^{1}-10^{3}$ copies/ $\mu \mathrm{L}$ in blood [14]. Hence SARS-CoV-2 colonizes the ME at comparable viral loads in our preliminary findings although additional samples are required to strengthen these comparisons. Moreover, given the lower viral loads observed in the ME tissue compared to the nasal cavity, we hypothesize that ME viral entry occurs via the eustachian tube, as previously demonstrated by other viral URT infections that lead to otitis media [5, 15]. However, circulation-mediated viral entry is also possible. Both the nasal cavity and ME epithelium express ACE2, the receptor known to interact with the SARS-CoV-2 spike protein for cell entry.

ME viral infection has been previously shown to contribute to otologic pathology and symptom manifestations such as $\mathrm{OM}$ and conductive hearing loss [5]. It is unclear if SARS-CoV-2 may further damage the auditory sensorineural system or if the COVID-19 symptoms of hearing loss and tinnitus may reflect the ototoxic effects of antiviral medications or immune mediators such as cytokines. However, the presence of viral loads in the ME could lead to direct inner ear SARS-CoV-2 infections. It is also possible that the virus triggers inner ear autoimmunity, known to produce hearing loss [16]. In our sample size 

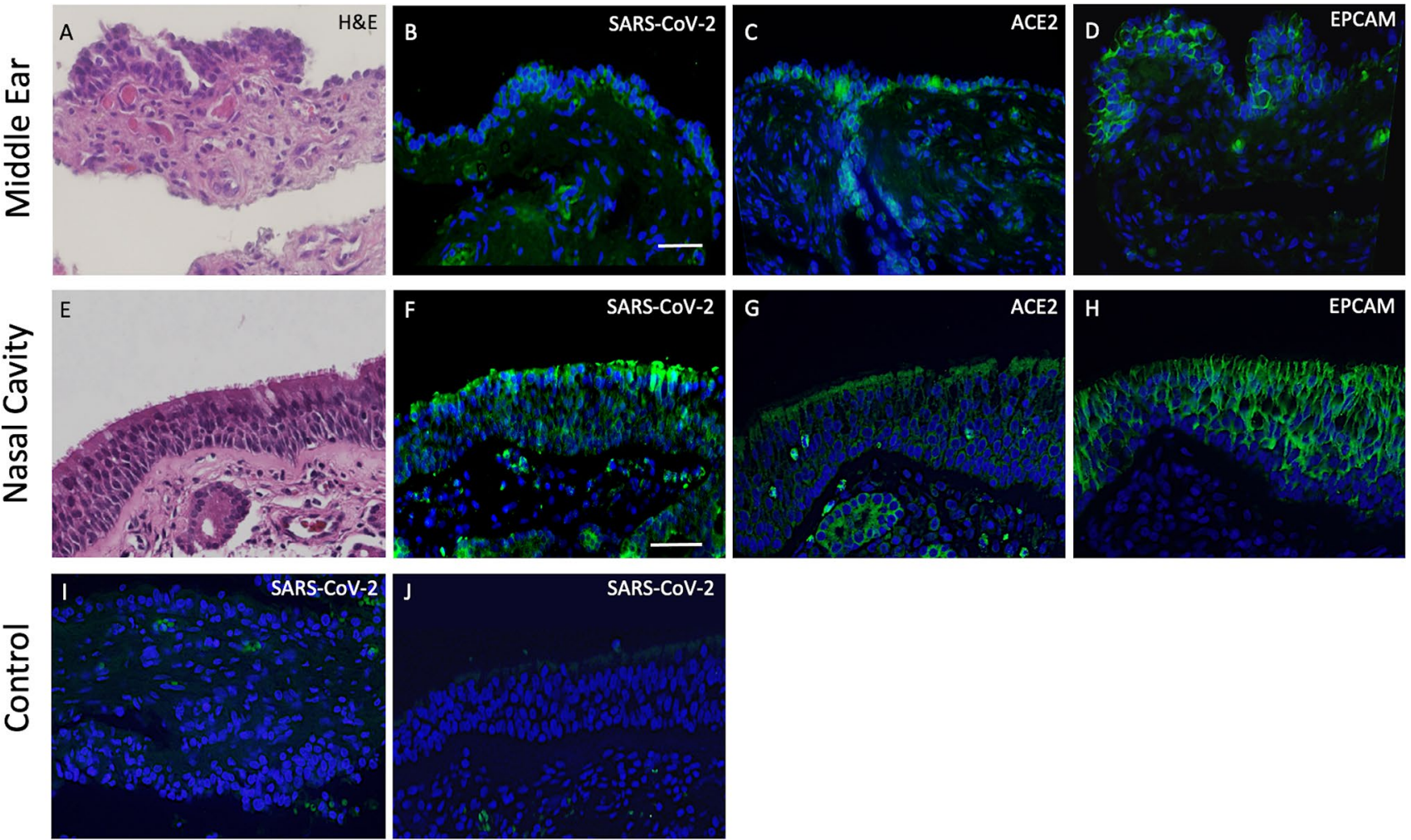

Fig. 2 H\&E and immunofluorescence staining of middle ear and nasal cavity tissues from COVID-19 and uninfected individuals. Histology A, E plus immunohistochemical localization of SARS-CoV-2 in epithelia of COVID-19 patients $(\mathbf{B}, \mathbf{F})$. Expression of ACE2 $(\mathbf{C}, \mathbf{G})$

of six COVID-19 patients, two had baseline hearing loss and none had reported COVID-19 related hearing loss. However, all suffered from abrupt clinical deterioration with ARDS and passed from COVID-19 complications, and thus milder otologic symptoms may have been overlooked. Further case studies on long-haul sequelae of COVID-19 survivors would shed more light on long-term effects. Our study is limited by its small sample size and future research regarding potential effects of COVID-19 on the ME and otologic symptomatology are warranted.

Author's Contributions AK wrote manuscript with input and review from all authors, generate figures. KP preform experiments and data collection. ASD IRBs and tissue collection. AFR results analyses and writing of manuscript. CHY supervised the project, result analyses, and generate figures.

Funding Supported by grants DC012595, DC000129 and DC014801 from the National Institute on Deafness and Other Communication Disorders (NIDCD), and BX001205 from the Veterans Administration. Supported by grants from the NIH/NIDCD, and the Veterans Administration.

Data Availability Any data is available upon request. was detected on surface epithelium identified by $\operatorname{EPCAM}(\mathbf{D}, \mathbf{H})$. No SARS-CoV-2 staining was seen in COVID-19 negative tissues (I, J), although RBCs showed autofluorescence

Code Availability Not applicable.

\section{Declarations}

Conflict of interest Dr. Ryan is a co-founder of Otonomy Inc., serves as a member of the Scientific Advisory Board, and holds an equity position in the company. The UCSD Committee on Conflict of Interest has approved this relationship. Otonomy, Inc. played no part in the research reported here. The remaining authors declare no competing interests.

Ethical approval Autopsy and use of human tissues was reviewed and approved by the Institutional Review Board of the University of California San Diego School of Medicine. (IRB\#191951 \& 151473).

Consent to Participate Consent was obtained per IRB and no personal identifying data is shared in the manuscript.

Consent for Publication Not applicable.

Open Access This article is licensed under a Creative Commons Attribution 4.0 International License, which permits use, sharing, adaptation, distribution and reproduction in any medium or format, as long as you give appropriate credit to the original author(s) and the source, provide a link to the Creative Commons licence, and indicate if changes were made. The images or other third party material in this article are included in the article's Creative Commons licence, unless indicated 
otherwise in a credit line to the material. If material is not included in the article's Creative Commons licence and your intended use is not permitted by statutory regulation or exceeds the permitted use, you will need to obtain permission directly from the copyright holder. To view a copy of this licence, visit http://creativecommons.org/licenses/by/4.0/.

\section{References}

1. Fidan V. New type of corona virus induced acute otitis media in adult. Am J Otolaryngol. 2020;41(3): 102487. https://doi.org/10. 1016/j.amjoto.2020.102487.

2. Almufarrij I, Uus K, Munro K. Does coronavirus affect the audiovestibular system? A rapid systematic review. Int J of Audiol. 2020;59(7):487-91. https://doi.org/10.1080/14992027.2020. 1776406.

3. Munro K, Uus K, Almufarrij I, Chaudhuri N, Yioe V. Persistent self-reported changes in hearing and tinnitus in post-hospitalisation COVID-19 cases. Int J of Audiol. 2020;59(12):889-90. https://doi.org/10.1080/14992027.2020.1798519.

4. Ruohola A, Pettigrew MM, Lindholm L, et al. Bacterial and viral interactions within the nasopharynx contribute to the risk of acute otitis media. J Infect. 2013;66(3):247-54. https://doi.org/ 10.1016/j.jinf.2012.12.002.

5. Bakaletz LO. Immunopathogenesis of polymicrobial otitis media. J Leukoc Biol. 2010;87:213-22. https://doi.org/10.1189/jib.07095 18.

6. Frazier KM, Hooper JE, Mostafa HH, Stewart CM. SARS-CoV-2 virus isolated from the mastoid and middle ear: implications for COVID-19 precautions during ear surgery [published correction appears in doi: https://doi.org/10.1001/jamaoto.2020.2950]. JAMA Otolaryngol Head Neck Surg 146(10):964-966. https:// doi.org/10.1001/jamaoto.2020.1922.

7. CDC website, Research use only 2019-novel coronavirus (2019$\mathrm{nCoV}$ ) real-time RT-PCR primers and probes, https://www.cdc. gov/coronavirus/2019-ncov/lab/rt-pcr-panel-primer-probes.html. Accessed March 12, 2020.

8. Liotti FM, Menchinelli G, Marchetti S, Morandotti GA, Sanguinetti M, Posteraro B, Cattani P. Evaluation of three commercial assays for SARS-CoV-2 molecular detection in upper respiratory tract samples. Eur J Clin Microbiol Infect Dis. 2021;40:269-77. https://doi.org/10.1007/s10096-020-04025-0.

9. Cantuti-Castelvetri L, Ojha R, Pedro LD, Djannatian M, Franz J, Kuivanen S, van der Meer F, Kallio K, Kaya T, Anastasina M, Smura T, Levanov L, Szirovicza L, Tobi A, Kallio-Kokko H,
Österlund P, Joensuu M, Meunier FA, Butcher SJ, Winkler MS, Mollenhauer B, Helenius A, Gokce O, Teesalu T, Hepojoki J, Vapalahti O, Stadelmann C, Balistreri G, Simons M. Neuropilin-1 facilitates SARS-CoV-2 cell entry and infectivity. Science. 2020;370(6518):856-60. https://doi.org/10.1126/science.abd29 85.

10. Liu J, Babka AM, Kearney BJ, Radoshitzky SR, Kuhn JH, Zeng $\mathrm{X}$. Molecular detection of SARS-CoV-2 in formalin fixed paraffin embedded specimens. bioRxiv. 2020;4(21):042911. https://doi. org/10.1172/jci.insight.139042.

11. Verhoeven D, Xu Q, Pichichero ME. Differential impact of respiratory syncytial virus and parainfluenza virus on the frequency of acute otitis media is explained by lower adaptive and innate immune responses in otitis-prone children. Clin Infect Dis. 2014;59(3):376-83. https://doi.org/10.1093/cid/ciu303.

12. Pettigrew MM, Gent JF, Pyles RB, Miller AL, Nokso-Koivisto $\mathrm{J}$, Chonmaitree T. Viral-bacterial interactions and risk of acute otitis media complicating upper respiratory tract infection. J Clin Microbiol. 2011;49(11):3750-5. https://doi.org/10.1128/JCM. 01186-11.

13. Chonmaitree T, Revai K, Grady JJ, Clos A, Patel JA, Nair S, Fan J, Henrickson KJ. Viral upper respiratory tract infection and otitis media complication in young children. Clin Infect Dis. 2008;46(6):815-23. https://doi.org/10.1086/528685.

14. Zheng S, Fan J, Yu F, Feng B, Lou B, Zou Q, Xie G, Lin S, Wang $\mathrm{R}$, Yang X, Chen W, Wang Q, Zhang D, Liu Y, Gong R, Ma Z, Lu S, Xiao Y, Gu Y, Zhang J, Yao H, Xu K, Lu X, Wei G, Zhou J, Fang Q, Cai H, Qiu Y, Sheng J, Chen Y, Liang T. Viral load dynamics and disease severity in patients infected with SARSCoV-2 in Zhejiang province, China, January-March 2020: retrospective cohort study. BMJ. 2020;369: m1443. https://doi.org/10. 1136/bmj.m1443.

15. Alper CM, Winther B, Mandel EM, Hendley JO, Doyle WJ. Rate of concurrent otitis media in upper respiratory tract infections with specific viruses. Arch Otolaryngol Head Neck Surg. 2009;135(1):17-21. https://doi.org/10.1001/archotol.135.1.17.

16. Harris JP, Keithley EM, Gopen Q. Autoimmune ear disease and other autoimmune diseases with inner ear involvement. In: Snow JB, Ballenger JJ, editors. Ballenger's Otorhinolaryngology: Head and Neck Surgery. Ontario: Hamilton; 2002. p. 396-407.

Publisher's Note Springer Nature remains neutral with regard to jurisdictional claims in published maps and institutional affiliations. 